\title{
New firm formation in the wake of mergers and acquisitions: An exploration of push and pull factors
}

\author{
Monia Lougui ${ }^{1} \cdot$ Anders Broström $^{2}$
}

Published online: 17 June 2020

(C) The Author(s) 2020

\begin{abstract}
This study investigates the relationship between mergers and acquisitions (M\&A) and entrepreneurial spawning in labour-intensive service sectors. We discuss two sets of theoretical mechanisms. First, M\&As may push employees into entrepreneurship by lowering the average barriers of leaving the current employment (i.e. being associated with general deterioration of working conditions). Second, M\&A activities may generate new entrepreneurial opportunities, which are first and foremost accessible by employees directly affected by M\&As. Results on entrepreneurial spawning in 3,198 Swedish firms during the time period 2000-2009 confirm that the number of firms spawned from a specific incumbent increases following an M\&A. Push-oriented factors are found to contribute to this effect, but a dominating part of the total effect remains in the presence of proxies for pusheffects. This suggests that pull-oriented explanations of opportunity creation in the wake of M\&As constitute an important avenue for further research on the antecedents of new firm formation.
\end{abstract}

Keywords firm formation · entrepreneurial spawning · mergers · acquisitions · opportunity costs · entrepreneurial opportunity

JEL classification s: L26 $\cdot \mathrm{G} 34 \cdot \mathrm{M} 50 \cdot \mathrm{L} 80$

Anders Broström

anders.brostrom@indek.kth.se

1 The Ratio Institute, Stockholm, Sweden

2 Department of Industrial Economics and Management, KTH Royal Institute of Technology, SE-100 44 Stockholm, Sweden 


\section{Introduction}

What are the antecedents of firm formation? This is one of the fundamental questions in the literature on entrepreneurship and self-employment. In recent years, a rich body of research on this topic has emerged in which firm formation is studied as a process with important links back to preceding organisations. Most importantly, this literature has highlighted links between new firms and those where a firm's founders have previously worked Sørensen and Fassiotto 2011; Buenstorf 2016). On the basis of evidence that the rate of entrepreneurial spawning differs considerably across incumbent firms (Burton et al. 2002), researchers have set out to identify the mechanisms that are at play. In the dominating strands of this literature, firm-level heterogeneity in entrepreneurial spawning is explained by differences in terms of capabilities, compensation policy and labour composition (Gompers et al. 2005; Habib et al. 2013). However, there also exists convincing - albeit somewhat scattered - evidence suggesting that firm-level turbulence such as new CEO arrival is related to the intensity of entrepreneurial spawning (Eriksson and Kuhn 2006).

In this paper, we extend this latter line of enquiry by analysing the effect of merger and acquisition (M\&A) activity on entrepreneurial spawning. Two main arguments are considered. First, we suggest that mergers and acquisitions may affect employees' transition to entrepreneurship by changing the general barrier to job mobility. Problems of acculturation after a merger (Larsson and Lubatkin 2001) and reduced fit between individual and organizational characteristics may lead to a perceived deterioration of career opportunities (Haveman and Cohen 1994), and thereby influence employees' perceived value of staying employed. On the other hand, M\&As may enhance the career prospects of employees. Management may also take action to keep key employees engaged throughout the process of integrating the merged entities. In other words, we note that the average opportunity cost of entrepreneurship for employees can be expected to be affected by M\&A activity. If the positive effect dominates, employees considering founding a new firm may abstain (or at least postpone) as a consequence of the M\&A event. If the negative effect dominates, and the opportunity costs of entrepreneurship decreases as a consequence of firm-level turmoil, employees may be "pushed" into acts of firm formation that they would otherwise not have engaged in.

Second, we draw on recent research inspired by evolutionary theory that suggests that M\&As pave the way for the creation of new entrepreneurial opportunities. In post-merger processes, consolidation of activities often lead firms to abandon smaller segments that are seen as strategically unaligned in order to focus on markets and products where significant economies of scale and scope can be realized (Gugler et al. 2003; Luksha 2008). M\&As can thus be conceived as creating room for niche markets and as creating novel opportunities that may be identified by Kirznernian entrepreneurs. Such opportunities are first and foremost identified by individuals with first-hand information about premerger activities, i.e. by employees of the merged firms. Parallel arguments suggest that M\&As can be expected also to drive entrepreneurship of a Schumpeterian nature. In particular, disagreement within a firm on the nature and potential of opportunities, or miss-match between an opportunity for new business and the incumbent's general strategy and existing line of products have 
been identified as important drivers of employee entrepreneurship (Klepper and Sleeper 2005; Klepper and Thompson 2010). As M\&As typically involve and bring about shifts in strategy, such tendencies can be expected to be reinforced in their wake. Employees affected by M\&As may hence also be understood as being "pulled" into entrepreneurship.

For the particular case of intra-industry spinouts in emerging high-tech industries, empirical results have verified that the rate of new firm formation increases following M\&As (see review in Klepper 2007). In this paper, we investigate whether M\&As are associated with increased entrepreneurial spawning also in a wider set of service sectors, including "low-tech" labour-intensive services. We also qualify the analysis by developing and empirically exploring the parallel arguments of a "pull" effect according to which M\&As create entrepreneurial opportunities and a "push" effect according to which M\&As reduce workers' reluctance to leave their existing job. While these arguments both suggest that entrepreneurial spawning may increase after an M\&A, they are associated with considerably different theoretical and practical implications.

Empirically, we investigate the spawn-rate of firms founded by employees of Swedish service sector firms during the time-period 2000-2009. Acknowledging that an observed relationship between M\&As and spin-out activity may be partly biased by simultaneity, e.g. in terms of unobserved industry-level developments, we utilize generalized structural equation model estimation. Our results confirm that entrepreneurial spawning is intensified in periods following an M\&A, albeit with a delay of two years. Moreover, the results provide evidence suggesting that while push factors do seem to play a role, a significant co-variation between M\&A activity and new firm formation remains after controlling for factors expected to proxy for the occurrence of such factors. We suggest that this finding may be interpreted as supporting the existence of pull factors, in the sense that M\&As may facilitate the creation of entrepreneurial opportunities.

\section{Theoretical context}

In establishing a basic theoretical framework for studying entrepreneurial spawning, our starting point is that the rate of new firms spawning from a focal firm changes with push and pull factors affecting the firm and its employees. Pull factors are any firm-level changes that increase the level of entrepreneurial opportunity among employees. Push factors leading to an increase in the spawning of new firms are any firm-level events that affect the firm's employees in such a way that they become more likely than before to shift from paid employment at the focal firm to self-employment in a new venture. Among extreme push factors are lay-offs at the focal firm. More generally, any event that negatively affects job satisfaction at the current firm, and that hence reduces the opportunity costs of self-employment for a non-trivial share of the firm's employees, would constitute such a push factor (Hyytinen and Ilmakunnas 2007). For example, transformative change of a firm's routines and strategic objectives may decrease the match between individual abilities and preferences on the one hand and job content on the other for some groups of employees. 


\subsection{Working conditions in post-merger and acquisition firms}

Achieving operational synergies between the merging entities is a common objective for post-M\&A integration processes (O'Shaughnessy and Flanagan 1998). In the short term, M\&As are therefore often associated with workforce downsizing. For example, Conyon et al. (2002) reported an average employment reduction of $8 \%$ for unrelated mergers and $19 \%$ for related mergers from a study of 442 UK mergers over the period 1967-1996. Being forced to look for a new source of income, it is plausible that some laid off employees may engage in venture creation. We may thus expect the rate of new firm formation from a parent firm to increase in post-M\&A periods.

The above argument can be extended beyond the extreme case of layoffs. Through its disruptive nature, an M\&A can be considered as a potential opportunity cost lowering factor also for many employees who are not directly laid off. M\&As often bring together organizational units with different activities, objectives, culture, and talent sets. While inter-organisational differences are typically more accentuated in the case of diversifying mergers, post-M\&A integration has proven a significant managerial challenge also when driven by the pursuit of scale economies (Gates and Very 2003). Re-orientation of strategic objectives, possibly including changes in management may create a mismatch between individual aspirations of the employees and firm management (Klepper and Thompson 2010). As a consequence, a number of employees may choose to depart from the firm, e.g. to form their own firms (Henderson and Clark 1990; Klepper and Sleeper 2005; Tushman and Anderson 1986).

The job characteristics theory (Seo and Hill 2005) associates an M\&A with deterioration of the working environment and a slump in employees' perception of work satisfaction. In addition to frustration and disappointment caused by firm policy shifts following an M\&As, employees sometimes experience a change in the fundamental relationships between the workers and the firm such as the disruption of psychological contracts as well as an interruption of the relationships and ties established among the colleagues (Newma and Krzystofiak 1993).

We should, as a consequence, observe increased employment turn-over - some of which may take the form of increased firm formation activity among employees (Amit et al. 1995; Sørensen and Sharkey 2014). In order words, M\&As may be expected to push employees not only to seek new employment but also to exert a push-effect increasing entrepreneurial spawning.

Arguments such as the above suggest that an M\&A would tend to increase the average reservation wage associated with the current job, i.e. to decrease the opportunity cost of leaving this job to engage in entrepreneurship. On the other hand, it can be argued that the exact opposite effect may also be plausible. Changes to the firm's strategic direction and to its operations brought about through M\&A processes may be welcomed by parts of the workforce. For some individuals, the workplace-individual fit will likely increase. Certain employees of smaller firms may, for example, appreciate the opportunity to climb the corporate career ladder in a larger firm context. In acquisitions where competence-seeking motives play a dominating role or where knowledge and networks embodied in staff constitute key commercial value, management may furthermore be willing to make particular efforts, including compensation increases, to retain key personnel (Ranft and Lord 2002). 
In view of these conflicting expectations, we present two competing hypotheses about the average impact of M\&As:

Hypothesis 1a: On average, M\&A events decrease the average opportunity cost of leaving the current job.

Hypothesis 1b: On average, M\&A events increase the average opportunity cost of leaving the current job.

\subsection{Mergers and acquisitions and the generation of entrepreneurial opportunities}

In recent research, M\&A activities have been suggested as a particularly interesting source of entrepreneurial opportunities (Buenstorf 2007). Despite typically perceived as making entry into the industry or industries affected by merger less attractive, due to the merged firm's new potential ability to exploit economies of scale and scope, M\&As may also be thought of as affecting the potential for entrepreneurship. Corporate restructuring and re-orientation in post-M\&A processes may create room for new forms of specialization along the value chain. For example, a newly merged firm may choose to abandon or divest selected business segments in order to achieve focus (Capron and Mitchell 1998; Friberg and Romahn 2012; Kaplan and Weisbach 1992), to avoid overlaps in assets (Chastain 1987) and to comply with antitrust policies. The creation of entrepreneurial opportunities may consequently be analyzed as an externality of M\&As.

M\&As can be expected to generate new entrepreneurial opportunities on an industry-wide level, in particular by creating room for niche markets. There are, however, reasons to believe that the effects of M\&A on entrepreneurial activities, at least in the short term, are strongly concentrated to employees of the merging firms. Employees are likely to have acquired knowledge and experience that make them better positioned than outsiders to identify and act on entrepreneurial opportunities generated in post-merger processes (Chastain 1987). Furthermore, as highlighted in a stream of work on strategic disagreement as a driver of spin-off activity (Klepper and Thompson 2010; Thompson and Chen 2011), such disagreement is particularly likely to arise in connection to changes in the control of a firm. Employees may be motivated by changed priorities in a newly merged firm to engage in entrepreneurship in order to exploit business opportunities that they find no longer fits with their employer's agenda; an opportunity which would not seem equally attractive (or even legally possible) as long as the incumbent firm was pursuing that line of development. To take a specific example, innovators in the employ of incumbents may be spurred to commercialize their ideas in the form of new ventures, if these ideas are not in line with the changed strategic orientation of the merged firm (Cassiman and Ueda 2006; Christensen 1993; Gambardella et al. 2015; Pakes and Nitzan 1983). More generally, opportunities to transfer some of their previous employer's routines into a new venture constitutes a source of potential advantage in terms of capability generation, as compared with entrepreneurial efforts by outsiders (Aldrich 1999). Firms founded by ex-employees are therefore better positioned than other firms to benefit from knowledge spillovers from the parent firm (Berchicci et al. 2011; Adams et al. 2019). 
There are several other possibilities for M\&A activities to provide existing employees with new entrepreneurial opportunities. Previous studies have investigated at least three such venues:

- Employees may be given formal offers to spin out as a merged firm undertakes divestures of an asset or an activity (Curranet al. 2012). Such divestitures can take the form of regular sell-offs, but also be pursued through liquidation or management buy-out (Hamilton and Chow 1993).

- For founder-owners, an acquisition typically frees up capital, and it is not unusual that this capital is reinvested in new ventures in the years following the M\&A event (Mason and Harrison 2006).

- M\&As may often generate uncertainty among existing customers, reducing loyalty to the incumbent firm and to the firm's brand (Homburg and Bucerius 2005; Jaju et al. 2006). Opportunities for entrepreneurship may thus arise, allowing employees to leverage their personal contacts to customers to continue serving their needs, albeit as private enterprisers rather than as employees (Campbell et al. 2012).

In summary, we suggest that through changing industry structure and firm priorities, M\&As increase employees' average evaluation of the best available opportunity for entrepreneurship. It follows from the presentation above that we expect such a change to result in an increased frequency of new firm formation. We specifically expect M\&As to constitute a pull-effect for employee entrepreneurship, holding constant any push-effects (i.e. a change in general willingness to leave the current job).

Hypothesis 2: Holding the average opportunity cost of leaving the current job constant, the rate of entrepreneurial spawning increases in periods following mergers and acquisitions.

\section{Methodology}

In order to test the hypotheses outlined in the previous section, we investigate firmlevel empirical data on M\&A activity and entrepreneurial spawning. In Fig. 1, the two sets of hypotheses are illustrated as a structural model of partial mediation (James et al. 2006). Hypothesis 1 suggests a relationship between M\&A and entrepreneurial spawning which is mediated by changes in the firm-averaged opportunity costs (OC) of job-switching. Hypothesis 2 suggests a complementary direct relationship between M\&A and entrepreneurial spawning, driven by an (empirically unobserved) change in entrepreneurial opportunity available to employees. Following convention, factors that are empirically observable are set in boxes, and unobserved (lateral) factors are set in oval shapes.

\subsection{Empirical strategy}

Our first hypothesis concerns the relationship between M\&A and employee job satisfaction. Let $\mathrm{OC}_{\mathrm{jt}}$ denote an empirical approximation of the opportunity cost of leaving the current job at firm $j$ in year $t$ and 


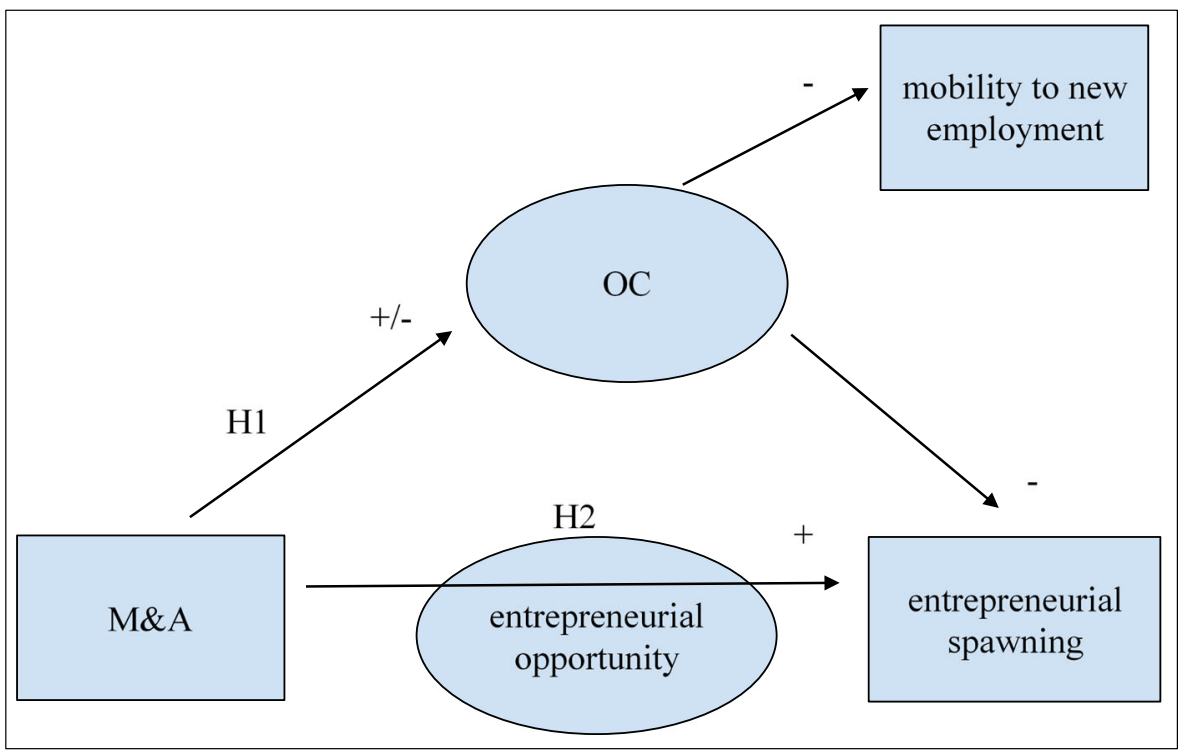

Fig. 1 Hypothesized relationships of partial mediation effects

$$
O C_{j t}=\alpha+\mu_{j}+\sum_{k=t-2}^{k=t}\left(\beta_{k}+\gamma_{k} F_{j k}\right) \times M A_{j t}+v C_{j t}+\partial_{t}+\gamma_{j}
$$

where MA is a dummy variable indicating that firm $j$ was involved in M\&A activity in year $t$ and $\mathrm{F}$ is a dummy variable indicating that the M\&A activity involves partners in more than one country $(=1)$, as opposed to purely domestic activity $(=0)$. The inclusion of $\mathrm{F}$ allows for potential heterogeneity in the effect of cross-border and domestic M\&As. For example, multinational M\&As may offer new career opportunities inside the firm (Bertrand 2009) to a larger extent than domestic M\&As. Or, with an oppositely directed connotation, cultural differences may induce additional post-M\&A frictions (Stahl and Voigt 2008). M\&As are allowed to affect the dependent variable with up to two years lag, reflecting a period of uncertainty about how firm strategy and working conditions will be affected by M\&A activities.

We quite naturally expect the firm-level opportunity cost of leaving the current employment to be positively associated with the performance of the firm, and negatively associated with the level of human capital. The vector $\boldsymbol{C}_{j t}$ contains corresponding control variables, to be further specified below. $\partial_{t}$ and $\gamma_{j}$ are vectors of year and firm specific effects, respectively.

We next model the frequency of employee entrepreneurship, in order to subject Hypothesis 2. to empirical examination. $S_{j t}$, the number of new firms spawned from each firm $j$ in each observed year $t$, is modelled as being related to both these variables and to a set of further variables:

$$
S_{j t}=\alpha+\mu_{j}+\sum_{k=t-2}^{k=t}\left(\omega_{k}+\gamma_{j} F_{j k}\right) \times M A_{j t}+\delta O C_{j k}+v C_{j t}+\lambda E_{j t}+\partial_{t}+\gamma_{j}
$$


As in Eq. 1, M\&A dummies and our empirical proxy for opportunity costs are allowed to affect spin-out activity with up to two years of lag, taking into account the delays involved in the entrepreneurial process. We also allow, through the introduction of the variable $\mathrm{F}$, for a differential impact of multinational and domestic M\&A activity.

The vector $\boldsymbol{C}_{j t}$ contains variables characterizing the focal firm. Firm size, measured as the number of employees of the focal firm in hundreds of individuals, is included here as the number of spinouts should be expected to be strongly related to the number of individuals "at risk" of participating in new firm formation. ${ }^{1}$ Acknowledging that better performing firms and firms with larger stocks of knowledge have been identified as more frequently spawning spinouts (Gompers et al. 2005), turnover per employee is included along with two variables measuring the education level of the workforce. Here, the share of employees with longer and shorter tertiary education are included, with the share of employees with secondary education or lower as their highest degree forming the base case. Finally, a set of dummy variables is used to denote the sector of activity, represented by a two-digit industry classification (NACE) code.

While controlling for generic sector idiosyncrasy, we have a particular interest in relating employee entrepreneurship activity to industry development more specifically. We note that M\&As are more likely to occur in phases of industry consolidation (Schoenberg and Reeves 1999), in the wake of technological change and during periods of economic expansion (Lambrecht 2004). These conditions are clearly also conducive for spin-out activities. While general entry levels can be expected to go down as industries are consolidated and competition hardens, niche creation will increase, offsetting some if not all of this disadvantage to spin-out entrants. Intensified technological change and an increased rate of economic expansion is generally conducive for entry. We could therefore expect to observe parallel increases in M\&A and employee entrepreneurship. Industry dynamics thus provide a set of alternative, non-causal arguments for a temporal linkage between the occurrence of M\&As and the spawning of spin-out firms.

In order to investigate these relationships, we introduce two further industry-level controls in Eq. 2. ${ }^{2} E_{j t}$ contains two variables capturing specified time-varying industryand year-specific conditions reflecting entry-conditions. These are an industry-level Herfindahl index and the rate of new firm formation (number of entrants divided by number of incumbents) by industry and region.

Equations 1 and 2 constitute a system, in that the dependent variable of Eq. 2 features as an independent variable in Eq. 1. Hence, we estimate our models both independently and, given the endogenous nature of our opportunity cost variable, jointly using structural equation modelling. We use the SEM estimation package of STATA 16 for this latter purpose. The dependent variable of Eq. (2) is a count variable

\footnotetext{
1 In a fixed-effect setting such as that of Eq. 2, the firm size variable may also capture the effect of workforce reductions at the focal firm on employee entrepreneurship. We expect, however, that since we explicitly control for opportunity costs in Eq. 2, this effect should be limited in the present context.

${ }^{2}$ Note that since Eq. 1 and Eq. 2 already includes industry-level fixed effects, any industry-level idiosyncracy affecting the dependent variable of these equations will already by captured. Our interest in including two industry-level variables in Eq. 2 is rather one of exploring a potential mechanism that may generate a pattern of temporal co-variation between M\&As and the intensity of employee entrepreneurship even in the absence of an actual causal linkage between these two phenomena.
} 
following a Poisson distribution with overdispersed variance suggesting the application of a negative binominal regression to our panel data.

\subsection{Data}

In our empirical analyses we use register-based employer-employee data collected by Statistics Sweden. This data has been used for a stream of previous studies on new firm formation and labour mobility (cf. Andersson and Klepper 2013; Baltzopoulos and Broström 2013; Delmar et al. 2011).

From firm-level data covering all Swedish firms over a nine-year period (2000 2009), we select firms based on their industrial classification. In view of our theoretical focus on settings where the relevant skills and entrepreneurial opportunities of employees are not strongly connected to immobile complementary assets and where the costs of greenfield entry are limited, we restrict our sample to firms classified as belonging to the labour-intensive service sector (Campbell et al. 2012; Teece 2003). This type of setting has only recently been subjected to study of employee entrepreneurship and inter-organizational heritage (Hunt et al. 2019). Choosing a setting with low entry costs, and with relatively low barriers to the transfer of routines and technology from the parent firm, is attractive for our study in that it makes factors such as innovativeness and technology strategy (which are unobservable in our type of data) less important both for firm formation and for the economic relevance of newly formed firms (see e.g. Thompson and Chen 2011).

We build our sample by first selecting data on all firms registered as belonging to a service sector. We subsequently drop observations on firms in a few sectors where employees' expertise may be connected to complementary assets that are difficult to transfer to an entrepreneurial venture due to regulation or to the involvement of capitalintensive production (e.g. banking, insurance, ferry traffic, air traffic, as well as electricity and water supply services). The sectorial composition of the final sample, by two digit NACE-code, is listed in Appendix Table 7. We restrict our analyses to firms with more than 50 employees which we are able to follow for at least three years of time.

Our firm data are merged with information on all working individuals in Sweden. Each individual is assigned to the firm in which (s)he is registered as being employed in the month of November of that year. ${ }^{3}$ We use these measures to identify events of entrepreneurial spawning, which we define as the establishment of new firms employing at least one individual who was in the previous year employed at the incumbent firm. A domestic M\&A is registered as having taken place when more than $50 \%$ of the individuals who worked in a firm in year $t-1$ are identified as working for a different firm in year $t$. We furthermore document the occurrence of cross-border M\&As, for which no employee data are available, using ownership data. Firms listed as foreign owned in year $t$ and as domestically held in year $t-1$ and firms listed as having domestic activity only in year $t-1$ and as having significant activity abroad in

\footnotetext{
3 If an individual receives wages from two firms in November, the firm from which the majority of taxable income is derived is selected as main employer. For individuals for whom one of these firms is a position of self-employment, Statistics Sweden multiplies wages by a factor 1.6 before comparing, in view of the relationship between the number of hours worked and taxable income having been found to be considerably different for this group of workers.
} 
year $t$ are classified as having been involved in M\&A activities (Andersson and Xiao 2016). ${ }^{4}$ In this way, 988 mergers are identified throughout the period. The sample used for this study consists of all firms that are involved in M\&A activities at least once, but not every year, during the window of observation. ${ }^{5}$ The resulting sample consists of 12,975 observations on 3,198 unique medium-sized and large firms. During the window of observation, employees at these firms found 18975 new firms. ${ }^{6}$

In contrast to much of the literature on spin-out creation, we are not restraining our study to individuals employed in 'high-tech' sectors or in particular occupations; our reasoning here applies to any employee for whom exploiting her skills, experience and networks in a venture is a viable alternative to remaining employed.

Whereas many studies have focused of intra-industry spin-out activity (Agarwal et al. 2004; Klepper and Sleeper 2005; Thompson and Chen 2011), we follow Franco and Filson 2006; Andersson and Klepper 2013; Yeganegi et al. 2016 who consider inter-industry and intra-industry spin-out formation as a joint phenomenon. A first basis for this decision is that previous research has demonstrated relatively strong skill relatedness between the service sectors that we study (Neffke and Henning 2013). While many of the most important routines of a manufacturing company may be embedded in a particular technological context, and therefore difficult to transfer to a new firm active outside the industry of the parent firm, the technology used by service firms is largely generic. As such, we believe many skills and experiences may be transferrable across industries in the service industry context.

Nonetheless, we acknowledge that routine transmission between a parent firm and its spawn may on average be greater for inter-industry spinouts than for intra-industry spinout activity. In consequence, our choice to include both types of firms may affect our ability to capture pull-factors. On the other hand, since a deterioration of working conditions can be expected to push employees into entrepreneurship in other industries than that of their current employer, our choice also implies that we avoid to underestimate the strength of push-factors. For the purpose of the present analysis, we consider this latter issue to have first priority, and hence as a second basis for our decision to jointly study intra-industry and inter-industry spin-out activity. The reader should, however, keep in mind that this choice may provide us with a conservative estimate of push-factors, and reduce the study's direct comparability with the literature on interindustry spinouts.

Finding empirical proxies for the opportunity cost of entrepreneurship is a significant challenge. The key difficulty in explicit study of opportunity costs lies in obtaining contra-factual information on what entrepreneurs would have earned in employment (Parker 2009). Reflecting such difficulties, opportunity cost perspectives are generally understudied in the empirical entrepreneurship literature. Attempts to measure

\footnotetext{
4 We acknowledge that we are probably, among the 212 events identified where firms with only Swedish activities expand to a new country, including a number of events of "greenfield" expansion. These should not be associated with firm-specific shocks to job satisfaction and to employee entrepreneurship. As any bias introduced by this method should be working in a direction against our two hypotheses, we are confident that this approximation will not spuriously drive our results towards confirming the hypotheses.

5 Since Eq. (2) contains firm fixed effects, identification requires variation in the dependent variable M\&A.

6 Two out of three of these firms have only one employee during their first year in operation. Roughly $3 \%$ of the new firms formed by employees employ 50 people or more already during their first year of operation, and can therefore be assumed to be related to buy-outs or divestment activities.
} 
explicitly opportunity cost in the context of entrepreneurship are few and far between. Amit et al. (1995) use cross-sectional differences in pre-entrepreneurship wage as proxy for differential opportunity costs of individuals in a study on transition into entrepreneurship. Cassar (2006) similarly uses household income as a measure of opportunity cost, driving the stated growth aspirations of entrepreneurs.Arora and Nandkumar 2011; Berkhout et al. 2016 extend the wage-based approach to opportunity costs by using information on wage of other individuals expected to face comparable labour market opportunities as the focal individual. In the first of these studies, such individuals are identified through their industry of employment and occupation, in the second by educational fields.

We exploit the richness of matched employer-employee data to construct two novel measures that we believe allows us to capture inter-temporal changes in the firm-level opportunity costs of leaving the current employment. Our primary measure is the observed returns to job mobility. For all individuals who between year $t-1$ and $t$ leave firm $j$ for a different paid employment (excluding people who enter into self-employment), we calculate the difference in salary between year $t$ and $t-1$. We subsequently calculate the arithmetic mean of these salary difference, and normalize this value by average wage-level of firm $j{ }^{7}$ This variable is used as our main proxy for opportunity costs, and is named consequently. For robustness check purposes, we also establish a related proxy in the form of the percentage of all employees at firm $j$ in year $t-1$ who are identified as having changed employer between year $t-1$ and $t$ while accepting a reduction in yearly salary. The two measures are complementary, in that they correspond to two different types of changes to the attractiveness of employment. The first measure has the advantage that it provides a metric describing how dramatic changes are across the firm, supposedly capturing the effects of extensive lay-offs and/or general deterioration of job satisfaction. The second measure, on the other hand, is intended to capture heterogeneous impact, where one group of employees is positively affected and another negatively affected by the firm-level development. While positive and negative impact of M\&As may well cancel each other out in terms of the firmlevel arithmetic mean, high values on this second measure provides an indication that for at least a sub-set of all employees, satisfaction with the current job is low. Individuals older than 60 are excluded from all calculations above, to avoid confusing retirement with other reasons for accepting a lower wage when switching jobs.

The Herfindahl index and the rate of new firm entry (the number of annual entrants divided by the number of incumbents) are calculated by aggregating data on industrylevel entry using two digit NACE-codes to identify industries. Table 1 below provides descriptive statistics of our dependent and independent variables. The table shows that the returns to job mobility (our main measure of opportunity costs) on average are $12 \%$. The final row of table (our alternative measure on opportunity costs) shows that on average, only $1.4 \%$ of a firm's employees switch to a new job where their registered wage income is reduced. The distribution of this variable is however very skewed; in $90 \%$ of all observation no individual is observed to make such a move while at the

\footnotetext{
7 Since values for this variable may be subject to noice in the data if based on only one or two departing individuals, we only consider means based on three or more annual departures from a focal firm.
} 
upper tail of the distribution we observe over 100 instances where more than a quarter of the workforce leaves a focal firm while seemingly accepting a lower wage in a new employment.

Correlations between variables in Table 1 are presented in Appendix Table 8.

\section{Results}

\subsection{Descriptive results}

Before going into estimation results, we may analyse the key hypothesized relationships through pure inspection of variables. Table 2 lists data underlying our variable Firm formation and our two measures of Opportunity costs, in the presence and absence of M\&A activities. The first row shows that the frequency of firm formation is somewhat intensified in years following an M\&A - in particular for observations on firms having experienced an M\&A two years ago. The two measures that we have constructed as proxies for opportunity costs change in the direction suggested by H1a. The average economic returns to job mobility are somewhat lower in merger and post-merger years, and it becomes more common for people to leave their job for a worse paid job in the year following an M\&A.

Table 1 Variables summary

\begin{tabular}{|c|c|c|c|c|c|}
\hline Variable name & Description & Mean & $\begin{array}{l}\text { Std. } \\
\text { Dev. }\end{array}$ & Min & Max \\
\hline Firm formation & Number of new firms spawned from focal firm & 1.315 & 4.378 & 0 & 125 \\
\hline Size & Number of employees (in thousands) & 0.2528 & 0.6756 & 0.050 & 1.4129 \\
\hline MA & M\&A activity & 0.052 & 0.223 & 0 & 1 \\
\hline $\mathrm{F}$ & Cross-border M\&A & 0.018 & 0.134 & 0 & 1 \\
\hline Turnover per employee & Turnover per employee in M SEK & 3.145 & 8.200 & 0 & 689 \\
\hline Low Education & $\begin{array}{l}\text { Share of employees with secondary level } \\
\text { education or lower education }\end{array}$ & 0.699 & 0.257 & 0.008 & 1 \\
\hline Medium Education & $\begin{array}{l}\text { Share of employees with less than } 3 \text { years } \\
\text { post-secondary education }\end{array}$ & 0.134 & 0.089 & 0 & 0.629 \\
\hline Long Education & $\begin{array}{l}\text { Share of employees with more than } 3 \text { years } \\
\text { post-secondary per employee }\end{array}$ & 0.167 & 0.204 & 0 & 0.981 \\
\hline Industry concentration & $\begin{array}{l}\text { Herfindahl index of the industry in which the } \\
\text { firm is active }\end{array}$ & 0.008 & 0.020 & 0.001 & 0.195 \\
\hline $\begin{array}{l}\text { Industry rate of new firm } \\
\text { formation }\end{array}$ & $\begin{array}{l}\text { Rate of new firm formation in the industry of the } \\
\text { focal firm }\end{array}$ & 0.185 & 0.072 & 0 & 0.4544 \\
\hline $\begin{array}{l}\text { Opportunity cost (main } \\
\text { measure) }\end{array}$ & $\begin{array}{l}\text { Mean difference between new and old wage for } \\
\text { job movers }\end{array}$ & 0.123 & 0.220 & 0 & 4.744 \\
\hline $\begin{array}{l}\text { Opportunity cost } \\
\text { (alternative measure) }\end{array}$ & $\begin{array}{l}\text { Share of employees who switch job while } \\
\text { accepting a lower wage }\end{array}$ & 0.014 & 0.041 & 0 & 0.6147 \\
\hline
\end{tabular}


Table 2 Descriptive analysis of key variables and merger activity

\begin{tabular}{lllll}
\hline Description & $\mathrm{MA}_{\mathrm{t}}=0$ & $\mathrm{MA}_{\mathrm{t}}=1$ & $\mathrm{MA}_{\mathrm{t}-1}=1$ & $\mathrm{MA}_{\mathrm{t}-2}=1$ \\
\hline Number of new firms spawned from focal firm & 1.37 & 1.73 & 1.73 & 2.15 \\
& $(4.51)$ & $(3.18)$ & $(3.12)$ & $(3.36)$ \\
Average wage increase of employees shifting to other employment & 0.035 & 0.026 & 0.030 & 0.023 \\
& $(0.120)$ & $(0.098)$ & $(0.085)$ & $(0.088)$ \\
Share of employees who switch job while accepting a lower wage & 0.012 & 0.014 & 0.035 & 0.011 \\
& $(0.032)$ & $(0.042)$ & $(0.087)$ & $(0.039)$ \\
\hline
\end{tabular}

Variable means, standard deviations in parenthesis

\subsection{Main results}

Table 3 reports the results of estimation of Eqs. 1 and 2, reported as models A and B respectively. Model A results, as reported in the first column of Table 3, show that the workforce of firms involved in M\&As are more likely to experience below-average opportunity cost of entrepreneurship. This result suggests that M\&A activity indeed is associated with a decrease in firm-level opportunity cost of job mobility, as stated by Hypothesis 1.

The results of Models B-1 and B-2 indicate a positive association between M\&As and employee entrepreneurship. Firm fixed effects included in the model capture any time-invariant difference across firms, including unobserved factors that may simultaneously affect the intensities of M\&A activity and entrepreneurial spawning, respectively. The control variable for firm size captures any change in entrepreneurial spawning only related to the number of individuals 'at risk'. The estimate on the M\&A variable hence indicates that in periods following M\&As, the level of entrepreneurial spawning is higher than it is in years with no recent M\&A activity.

This result is in itself novel. While Klepper and Sleeper (2005) and Klepper and Thompson (2010) have reported similar results from analyses of intra-industry spin-out activity in the laser, automobile and semiconductor industries, the present finding implies a more general temporal correlation between M\&As and entrepreneurial spawning.

The significantly negative estimates on the opportunity cost of job switching in Models B-1 and B-2 imply that periods where job switchers are compensated better than in the average year for leaving the focal firm are associated with a decrease in the level of entrepreneurial spawning. Reflecting the delays involved in job switching and in setting up a new firm, this effect only materialises, however, with a two-year delay. That is, two years after many employees are observed to be leaving the firm with low or even negative impact on their wage, the number of spinouts spawned from the focal firm is observed to increase. We interpret these results as supporting H1a, the first of our two competing hypotheses on the relationship between opportunity costs and firm formation. 
Table 3 Main results

\begin{tabular}{|c|c|c|c|c|}
\hline & Model A-1 & Model B-1 & Model A-2 & Model B-2 \\
\hline Estimator & OLS & Negative binomial & OLS & $\begin{array}{l}\text { Negative } \\
\text { binomial }\end{array}$ \\
\hline Estimation approach & Separate model & Separate model & SEM & SEM \\
\hline Dependent variable & $\begin{array}{l}\ln \text { (opportunity } \\
\quad \text { cost) }\end{array}$ & firm formation & $\begin{array}{l}\ln (\text { opportunity } \\
\quad \text { cost) }\end{array}$ & $\begin{array}{l}\text { firm } \\
\text { formation }\end{array}$ \\
\hline \multirow[t]{2}{*}{$\mathrm{MA}_{\mathrm{t}}$} & $-0.024 *$ & 0.0497 & -0.0226 & $0.1224 *$ \\
\hline & $(0.0357)$ & $(0.0470)$ & $(0.0122)$ & $(0.0517)$ \\
\hline \multirow{2}{*}{$\mathrm{MA}_{\mathrm{t}-1}$} & $-0.1889 * *$ & 0.0048 & $-0.0332 * *$ & 0.0957 \\
\hline & $(0.0427)$ & $(0.0485)$ & $(0.0119)$ & $(0.0506)$ \\
\hline \multirow[t]{2}{*}{$\mathrm{MA}_{\mathrm{t}-2}$} & 0.0223 & $0.1607^{* *}$ & 0.0084 & $0.3230 * *$ \\
\hline & $(0.0571)$ & $(0.0571)$ & $(0.0239)$ & $(0.0758)$ \\
\hline \multirow[t]{2}{*}{$\mathrm{F} \times \mathrm{MA}_{\mathrm{t}}$} & $0.5691^{* *}$ & -0.0266 & $0.1110^{* *}$ & -0.0159 \\
\hline & $(0.0578)$ & $(0.0863)$ & $(0.0202)$ & $(0.0894)$ \\
\hline \multirow[t]{2}{*}{$\mathrm{F} \times \mathrm{MA}_{\mathrm{t}-1}$} & $0.4476^{* *}$ & -0.1131 & $0.0597 * *$ & -0.0763 \\
\hline & $(0.0716)$ & $(0.0881)$ & $(0.0196)$ & $(0.0883)$ \\
\hline \multirow[t]{2}{*}{$\mathrm{F} \times \mathrm{M} \& \mathrm{~A}_{\mathrm{t}-2}$} & $0.2367 * *$ & -0.1343 & 0.0165 & -0.2051 \\
\hline & $(0.0624)$ & $(0.0929)$ & $(0.0300)$ & $(0.1079)$ \\
\hline \multirow[t]{2}{*}{ size $_{t}$} & 0.0205 & $0.2075^{* *}$ & 0.0066 & $0.7509 * *$ \\
\hline & $(0.0481)$ & $(0.0230)$ & $(0.0048)$ & $(0.0137)$ \\
\hline \multirow[t]{2}{*}{$\ln \left(\right.$ turnover per employee $\left.{ }_{t}\right)$} & -0.0204 & -0.0098 & $0.0232 * *$ & $-0.0995 * *$ \\
\hline & $(0.0223)$ & $(0.0069)$ & $(0.0038)$ & $(0.0207)$ \\
\hline \multirow[t]{2}{*}{ medium education $_{t}$} & 0.2602 & -0.1058 & $0.0926^{*}$ & $1.0880 * *$ \\
\hline & $(0.2969)$ & $(0.4323)$ & $(0.0374)$ & $(0.2044)$ \\
\hline \multirow[t]{2}{*}{ long education ${ }_{t}$} & -0.2675 & $0.6682 *$ & $0.0555^{* *}$ & $0.9649 * *$ \\
\hline & $(0.2507)$ & $(0.2759)$ & $(0.0181)$ & $(0.0976)$ \\
\hline \multirow[t]{2}{*}{$\ln \left(\right.$ opportunity cost $\left.t_{t}\right)$} & & -0.0002 & & 0.0157 \\
\hline & & $(0.0471)$ & & $(0.0418)$ \\
\hline \multirow[t]{2}{*}{$\ln \left(\right.$ opportunity $\operatorname{cost}_{\mathrm{t}-1}$ ) } & & 0.0354 & & 0.0521 \\
\hline & & $(0.0466)$ & & $(0.0425)$ \\
\hline \multirow[t]{2}{*}{$\ln \left(\right.$ opportunity $\operatorname{cost}_{\mathrm{t}-2}$ ) } & & $-0.1001^{*}$ & & $-0.0789 *$ \\
\hline & & $(0.0463)$ & & $(0.0315)$ \\
\hline \multirow[t]{2}{*}{ industry concentration $_{t}$} & & $-8.6999 * *$ & & $-2.1313^{*}$ \\
\hline & & $(1.5807)$ & & $(0.8358)$ \\
\hline \multirow[t]{2}{*}{ industry rate of new firm formation ${ }_{t}$} & & $-1.1977 * *$ & & -0.4872 \\
\hline & & $(0.4524)$ & & $(0.3218)$ \\
\hline Year fixed effects & Included & Included & Included & Included \\
\hline Industry fixed effects & Included & Included & Included & Included \\
\hline \multirow{3}{*}{$\begin{array}{l}\text { Firm fixed effects } \\
\text { cons }\end{array}$} & Included & Included & Included & Included \\
\hline & 0.2756 & $1.144 * *$ & $1.1644 * *$ & $-0.5370 * *$ \\
\hline & $(0.1483)$ & $(0.2195)$ & $(0.0189)$ & $(0.1022)$ \\
\hline
\end{tabular}

Coefficient estimates with robust standard errors in parenthesis

**Coefficient significant at a $1 \%$ level; *Coefficient significant at a $5 \%$ level 
While allowing for dynamic relationships involving our measures on changes in firm-level opportunity cost and changes in industry structure in Models B-1 and B-2, a strong link between M\&As and spin-out activities remains. In the two-year window of observation applied in this study, M\&As bring about a net increase in spin-out activity from a firm which does not seem to be explained either by changes in opportunity cost brought about by e.g. deterioration of job satisfaction, nor by changes in opportunity cost related to an upswing in performance of the focal firm. We argue that it is reasonable to interpret the outcome of this exploratory analysis as providing support for the view of M\&As as generating externalities in the form of entrepreneurial opportunities. Our findings would thus seem to provide support for Hypothesis 2.

We note that our two estimation approaches yield somewhat different results regarding the level of this effect. Model B-1 results suggests an M\&A to be associated with a 16 percent increase in the frequency of firm formation, whereas the system estimation reported in Model B-2 suggests an impact of $12+32$ percent over three years time.

In Table 4, we re-estimate the models of Table 3 using our alternative proxy for opportunity costs (i.e. the negated share of employees moving to new employment while accepting a lower wage income). The results are largely consistent with those obtained above as regards evaluation of our hypotheses. However, there are interesting differences in the timing of the effects. The alternative measure of opportunity costs effects firm formation directly, whereas there is a delay of two years between a spike in the first proxy measure and increased employee entrepreneurship. A possible interpretation is that the alternative measure tends to capture more acute causes of worker mobility, including lay-offs. For more general employee dissatisfaction with the development of their firm in terms of, e.g., strategic direction or workplace culture, it would not seem unreasonable to find a two year delay between an M\&A and spin-out activity. Such time may be required to evaluate the consequences of the organizational change, and also used to prepare a move into self-employment.

On a final note regarding the various estimation results for Model B, we note that industry concentration is found to be negatively associated with the frequency of entrepreneurial spawning. Furthermore, industry entry-levels are mostly negatively associated with employee entrepreneurship. These results would seem congruent with the view that mergers or exits in an industry may stimulate entry not only among employees of the directly concerned firms, but also to some extent among employees of competitors, and that such activity is also sensitive to increases in competition.

\subsection{Robustness tests and extensions}

We run several alternative specifications to ensure the robustness of the results reported above. First, we note that key results are valid also when substituting the estimator of model B for traditional OLS, and when leaving out year and industry fixed effects (which in general are highly significant in models A and B). Second, we extend the model within the flexible SEM framework to model explicitly 
Table 4 Results for alternative measure for opportunity costs

\begin{tabular}{|c|c|c|c|}
\hline & Model A-3 & Model B-3 & Model B-4 \\
\hline Estimator & OLS & Negative binomial & Negative binomial \\
\hline Estimation approach & Separate model & Separate model & Separate model \\
\hline Dependent variable & $\ln ($ opportunity cost) & firm formation & firm formation \\
\hline \multirow[t]{2}{*}{$\mathrm{MA}_{\mathrm{t}}$} & -0.0027 & 0.0548 & 0.0549 \\
\hline & $(0.0021)$ & $(0.0469)$ & $(0.0489)$ \\
\hline \multirow{2}{*}{$\mathrm{MA}_{\mathrm{t}-1}$} & $-0.0383^{* *}$ & -0.0073 & -0.0068 \\
\hline & $(0.0049)$ & $(0.0490)$ & $(0.0489)$ \\
\hline \multirow[t]{2}{*}{$\mathrm{MA}_{\mathrm{t}-2}$} & -0.0032 & $0.1593 * *$ & $0.1596^{* *}$ \\
\hline & $(0.0020)$ & $(0.0570)$ & $(0.0570)$ \\
\hline \multirow[t]{2}{*}{$\mathrm{F} \times \mathrm{MA}_{\mathrm{t}}$} & $0.0186^{* *}$ & -0.0239 & -0.0246 \\
\hline & $(0.0033)$ & $(0.0850)$ & $(0.0856)$ \\
\hline \multirow[t]{2}{*}{$\mathrm{F} \times \mathrm{MA}_{\mathrm{t}-1}$} & $0.0434 * *$ & -0.1017 & -0.1220 \\
\hline & $(0.0056)$ & $(0.0870)$ & $(0.0874)$ \\
\hline \multirow[t]{2}{*}{$\mathrm{F} \times \mathrm{M} \& \mathrm{~A}_{\mathrm{t}-2}$} & 0.0064 & -0.1556 & -0.1543 \\
\hline & $(0.0038)$ & $(0.0931)$ & $(0.0930)$ \\
\hline \multirow[t]{2}{*}{ size $_{t}$} & 0.0008 & $0.2059 * *$ & $0.2064 * *$ \\
\hline & $(0.0029)$ & $(0.0232)$ & $(0.0233)$ \\
\hline \multirow[t]{2}{*}{$\ln \left(\right.$ turnover per employee $\left.{ }_{t}\right)$} & -0.0003 & $-0.1246^{* *}$ & $-0.1237 * *$ \\
\hline & $(0.0018)$ & $(0.0377)$ & $(0.0377)$ \\
\hline \multirow[t]{2}{*}{ medium education $_{\mathrm{t}}$} & -0.0038 & -0.0604 & -0.0600 \\
\hline & $(0.0156)$ & $(0.4321)$ & $(0.4324)$ \\
\hline \multirow[t]{2}{*}{ long education ${ }_{t}$} & 0.0016 & $0.6786^{*}$ & $0.6758 *$ \\
\hline & $(0.0023)$ & $(0.2764)$ & $(0.2767)$ \\
\hline \multicolumn{3}{|l|}{ opportunity cost $t_{t}$} & -0.0034 \\
\hline \multicolumn{3}{|l|}{ (main measure) } & $(0.0468)$ \\
\hline \multicolumn{3}{|l|}{ opportunity $\operatorname{cost}_{\mathrm{t}-1}$} & 0.0332 \\
\hline \multicolumn{3}{|l|}{ (main measure) } & $(0.0468)$ \\
\hline \multicolumn{3}{|l|}{ opportunity $\operatorname{cost}_{\mathrm{t}-2}$} & $0.0998^{*}$ \\
\hline \multicolumn{3}{|l|}{ (main measure) } & $(0.0463)$ \\
\hline \multicolumn{2}{|l|}{ opportunity $\operatorname{cost}_{\mathrm{t}}$} & $-0.8707 * *$ & $-0.8679 * *$ \\
\hline \multicolumn{2}{|l|}{ (alternative measure) } & $(0.3153)$ & $(0.3158)$ \\
\hline \multicolumn{2}{|l|}{ 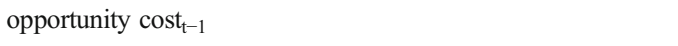 } & 0.5622 & 0.5589 \\
\hline \multicolumn{2}{|l|}{ (alternative measure) } & $(0.4423)$ & $(0.4431)$ \\
\hline \multicolumn{2}{|l|}{ opportunity $\operatorname{cost}_{\mathrm{t}-2}$} & -0.1701 & -0.1673 \\
\hline \multicolumn{2}{|l|}{ (alternative measure) } & $(0.3745)$ & $(0.3749)$ \\
\hline \multirow{2}{*}{\multicolumn{2}{|c|}{ industry concentration $_{t}$}} & $-8.5938^{* *}$ & $-8.6770 * *$ \\
\hline & & $(1.5834)$ & $(1.5835)$ \\
\hline \multirow[t]{2}{*}{ industry rate of new firm formation ${ }_{t}$} & & $-1.1844 *$ & $-1.1915^{* *}$ \\
\hline & & $(0.4526)$ & $(0.4526)$ \\
\hline Year fixed effects & Included & Included & Included \\
\hline Industry fixed effects & Included & Included & Included \\
\hline Firm fixed effects & Included & Included & Included \\
\hline
\end{tabular}


Table 4 (continued)

\begin{tabular}{llll}
\hline & Model A-3 & Model B-3 & Model B-4 \\
\hline cons & $\begin{array}{l}0.2756 \\
(0.1483)\end{array}$ & $\begin{array}{l}0.8539 * * \\
(0.2076)\end{array}$ & $\begin{array}{c}0.4172 * * \\
(0.0524)\end{array}$ \\
\hline
\end{tabular}

Coefficient estimates with robust standard errors in parenthesis

**Coefficient significant at a $1 \%$ level; ${ }^{*}$ Coefficient significant at a $5 \%$ level

multicollinearity between the M\&A variable and firm size in up to two years after the event (i.e. acknowledging firm size being bumped up through a merger and the possibility of post-M\&A lay-offs). We further investigate whether results are primarily driven by observations on mergers between firms of relatively similar size, or whether they apply to the more general context of mergers $\&$ acquisitions. Specifically, we modify the main models A-1 and B-1 to include a moderating factor Equal size $M \& A$, in the form of a variable which takes the value 1 if a firm is registered as having merged with another firm in a given year, but where no more than 50\% of the merged firm's employees were working for the focal firm in the year before. As shown in Appendix Table 9, estimates on this variable are not significant. We therefore conclude that our results apply also to organizational change involving firms of different original size.

In order to test the construct validity of our proxy for changes in firm-averaged opportunity costs, and the validity of our interpretations regarding hypothesis 2 , we conduct further empirical work. First, we compare M\&As to regular exits. A regular exit should reduce the firm-averaged opportunity costs of moving into self-employment (Eriksson and Kuhn 2006; Andersson and Klepper 2013). We thus expect our proxy for opportunity costs to be negatively associated with the occurrence of an exit. We investigate this notion by introducing the variable exit as a dichotomous variable indicating whether a firm has ceased to operate into models A and B of Table 3. Key results are shown in Table 5.

This first set of extended analysis confirms that exits have significant impact on our measure of opportunity costs. ${ }^{8}$ As expected, we furthermore find that the rate of entrepreneurial spawning increases in periods after exits. In contrast to M\&As, however, this effect is completely mediated through changes in the opportunity cost measure. That is, exit does not significantly explain number of spinouts once controlling for opportunity cost. This finding corroborates that our empirical proxy for opportunity costs captures a relevant portion of actual changes in employees' outside labour market options, constituting potential push-factors for employee entrepreneurship. Had the temporal covariation between M\&As and an intensified rate of employee entrepreneurship (as observed in Table 2) been driven entirely by a deterioration of working conditions, we should have expected to find

\footnotetext{
8 Note that we cannot, as we did with the MA variable, include lagged version of the exit variable in the analysis mimic the structure of Table 3; since firms cease to exist after they exit, the lagged value of the exit variable takes the value 0 for all observed firms. Since the conditions leading to an exit may be expected to affect employees and their motivation for job mobility already before the exit takes place, we include a forward lag in Table 5.
} 
Table 5 The impact of regular exits

\begin{tabular}{lll}
\hline & Model A-4 & Model B-5 \\
\hline Dependent variable & $\ln$ (opportunity cost) & number of spinouts \\
exit ${ }_{\mathrm{t}+1}$ & -0.0577 & -0.5905 \\
& $(0.0565)$ & $(0.7316)$ \\
exit $_{\mathrm{t}}$ & $-0.1137^{*}$ & 0.3431 \\
& $(0.0575)$ & $(0.5110)$ \\
$\ln \left(\right.$ Opportunity cost $\left.\mathrm{t}_{\mathrm{f}}\right)$ & & -0.0210 \\
& & $(0.0513)$ \\
$\ln \left(\right.$ Opportunity cost $\left.\mathrm{t}_{\mathrm{t}-1}\right)$ & & 0.0690 \\
& & $(0.0490)$ \\
$\ln \left(\right.$ Opportunity cost $\left.\mathrm{t}_{\mathrm{t}-2}\right)$ & & $0.1019^{*}$ \\
& & $(0.0494)$ \\
same set of control variables as in in Table 3 & yes & yes \\
\hline
\end{tabular}

Coefficient estimates with robust standard errors in parenthesis

$* *$ Coefficient significant at a $1 \%$ level; *Coefficient significant at a $5 \%$ level

a pattern of full mediation (i.e. insignificant estimates on the MA-variables) in the results reported in Table 3 .

In a second extension, we study the performance of spinouts conditional on entry. Our expectation is that entrepreneurial spawning occurring in years when opportunity costs are low should be less likely to result in viably growing new ventures. Spinouts formed in the presence of low opportunity costs are more likely to be "pushed", and as such have lower potential and/or entrepreneurial ambition (Andersson and Klepper 2013). To investigate this expectation, we introduce the variable employment growth. For each 'mother' firm and year, this variable lists the average employment growth of all ventures created during their first three years in existence. We model the logged value of this variable as a function of all covariates in model B of Table 3, and estimate this model using the OLS estimator. Key results are shown in Table 6. We find that our measure of opportunity costs indeed is correlated with spin-out performance. Controlling for changes in firm-averaged opportunity cost over time, there is also a direct effect of MA on employment growth. This finding is clearly compatible with the idea of M\&As as a source of novel entrepreneurial opportunity. Firms founded in periods following an M\&A and/or in periods with high levels of opportunity costs (as driven by e.g. increases in job satisfaction) are less likely than other new firms to be shaped in a context of necessity entrepreneurship.

From these two exercises, we conclude that our empirical proxy of opportunity costs behaves in a way that is consistent with theoretical expectations. Together, these two sets of results increases our confidence in the proxy. They also corroborate the view that the results presented in Table 3 may indicate the presence of non-negligible pullfactors for employee entrepreneurship in the wake of M\&A activity. 
Table 6 Model of employment growth in a firm's spawns

\begin{tabular}{ll}
\hline Dependent variable & $\ln ($ employment growth) \\
\hline $\mathrm{MA}_{\mathrm{t}}$ & -0.0039 \\
$\mathrm{MA}_{\mathrm{t}-1}$ & $(0.0186)$ \\
$\mathrm{MA}_{\mathrm{t}-2}$ & 0.0090 \\
& $(0.0203)$ \\
$\ln ($ Opportunity cost & \\
& 0.0532 \\
$\ln ($ Opportunity cost & \\
& $(0.0331)$ \\
$\ln ($ Opportunity cost & \\
& 0.0107 \\
same set of control variables as in Table 3 & $(0.0110)$ \\
\hline
\end{tabular}

Coefficient estimates with robust standard errors in parenthesis.

$* *$ Coefficient significant at a $1 \%$ level; *Coefficient significant at a $5 \%$ level

\section{Conclusion}

Mergers and acquisitions (M\&As) have been identified as a central mechanism of market based economies. As demonstrated by Williamson (1968), a horizontal merger or acquisition may increase economic efficiency if it allows for the exploitation of previously unutilized economies of scale and scope that may well be greater than the efficiency loses incurred by the merged firm's increased market power. Furthermore, M\&As potentially affect long-term economic development through transforming the conditions for industry-wide level innovation activities, but the accumulated evidence suggests that the net impact is subject to a number of contingencies (Cassiman and Colombo 2006; Cloodt et al. 2006). In this paper, we explore an additional route through which M\&A activity may affect the evolution of an industry: through affecting the conditions for entrepreneurial activity among employees of the involved firms. We conceptualise M\&A activity as an important mediator of evolutionary industrial change, within and across markets, through entrepreneurial actions (Witt 2002; Sarasvathy and Dew 2005).

We introduce a methodological novelty in that we develop and test measures on (intertemporal changes in) the firm-specific opportunity cost of entrepreneurship for employees. These measures are shown to mediate fully the linkage between firm exit and employee entrepreneurship and to predict early-stage performance of employee ventures, which strengthens our confidence in the measures as meaningful proxies for opportunity costs. Utilizing these measures, our analysis offers three sets of results contributing to the literature on entrepreneurial spawning on the one hand and the literature on the effects of M\&A activity on the other. 
First, we show that the empirical regularity that employee entrepreneurship intensifies in the wake of M\&As extends from the context of emerging high-tech industries such as lasers, semiconductors and disk-drives (Klepper and Thompson 2006) to a wider setting of labour-intensive service sectors. In this setting, which has been largely underexplored in extant scholarship on employee entrepreneurship and firm formation (Hunt et al. 2019), we identify a two-year delay between a fusion of two or more existing firms and an increase in spin-out activity. We also find some indications of that this effect is primarily in place for domestic M\&As.

Second, we provide evidence suggesting that M\&As on average reduces the opportunity cost of entrepreneurship for employees, and that this accounts for part of the observed linkage between M\&As and spin-out activity. This finding suggest that push factors are at play, i.e. that M\&As stimulate entrepreneurial spawning though deterioration of local labour conditions. However, this is only true for domestic M\&As. For the case of firm ownership shifting into foreign hands, we find opposite - and much stronger - effects on both measures we use as proxies for the opportunity cost of entrepreneurship. While we caution against generalising this finding beyond the setting studied here (i.e. the Swedish manual service during the $00 \mathrm{~s}$ ), these differences call for further investigation of heterogeneity in the impact of M\&A activity on worker job satisfaction.

Third, we explore the possibility that M\&As generate new entrepreneurial opportunities for employees, e.g. by creating room for niche markets (Luksha 2008), by shaking the loyalty of the mother firm's customers (Homburg and Bucerius 2005), and by inducing employees to pursue discontinued products, services and lines of development in the form of entrepreneurial activities (Klepper and Sleeper 2005; Klepper and Thompson 2010). In contrast to "pushed" entrepreneurship, such "pulled" entrepreneurship has potentially positive connotations from a welfare perspective. Empirically, we show that also when controlling for the opportunity cost effect and for industry factors that may introduce simultaneity between M\&As and increased spin-out activity, a strong temporal linkage between the two remains. In other words: we find that the relationship between M\&As and entrepreneurial spawning is only partly mediated by "push" factors. Our results leave considerable room for an interpretation that the dominating mechanism through which M\&As are associated with spin-out activities is that entrepreneurial opportunities are created, "pulling" employees into entrepreneurship.

The present analysis is subject to several limitations, in particular as regards empirical operationalization. While we have advanced and tested a novel empirical proxy for opportunity costs in order to investigate 'push' and 'pull' forces behind entrepreneurial spawning, our analysis of the latter type of mechanism is of an indirect, residual nature. We are also not able to distinguish empirically between the different mechanisms that we have suggested could pull people into entrepreneurship in the wake of M\&As. Hence, we have not been able to conduct any analysis to investigate, e.g., to what extent spinouts are founded on the basis of divesture decisions or on disruptions in incumbent-customer relationships in the context of an M\&A. To further advance the research agenda outlined in this paper, further work would seem motivated. In particular, such work may set out to conduct more direct systematic investigation of opportunities for entrepreneurship 
that are created and/or strengthened as a consequence of M\&A activity. Further work is also needed to address the question whether there are alternative mechanisms that link the occurrence of M\&As and spin-out activity, which do not fit within the entrepreneurial opportunities framework.

Acknowledgements The authors are grateful to participants at the DRUID Summer, DRUID Winter and EARIE conferences for constructive comments on previous versions of the manuscript.

Funding Information Open Access funding provided by Royal Institute of Technology.

\section{Compliance with ethical standards}

Conflict of interest The authors declare that they have no conflict of interest.

\section{Appendix 1}

Table 7 List of sectors included

\begin{tabular}{ll}
\hline Sector & Share in sample \\
\hline Construction and real estate activities & $21 \%$ \\
Wholesale & $25 \%$ \\
Retail & $7 \%$ \\
Hotels and restaurants & $11 \%$ \\
Transport and logistics & $5 \%$ \\
Knowledge intensive business services (ICT, consulting, R\&D) & $22 \%$ \\
Health, education and media services & $8 \%$ \\
\hline
\end{tabular}




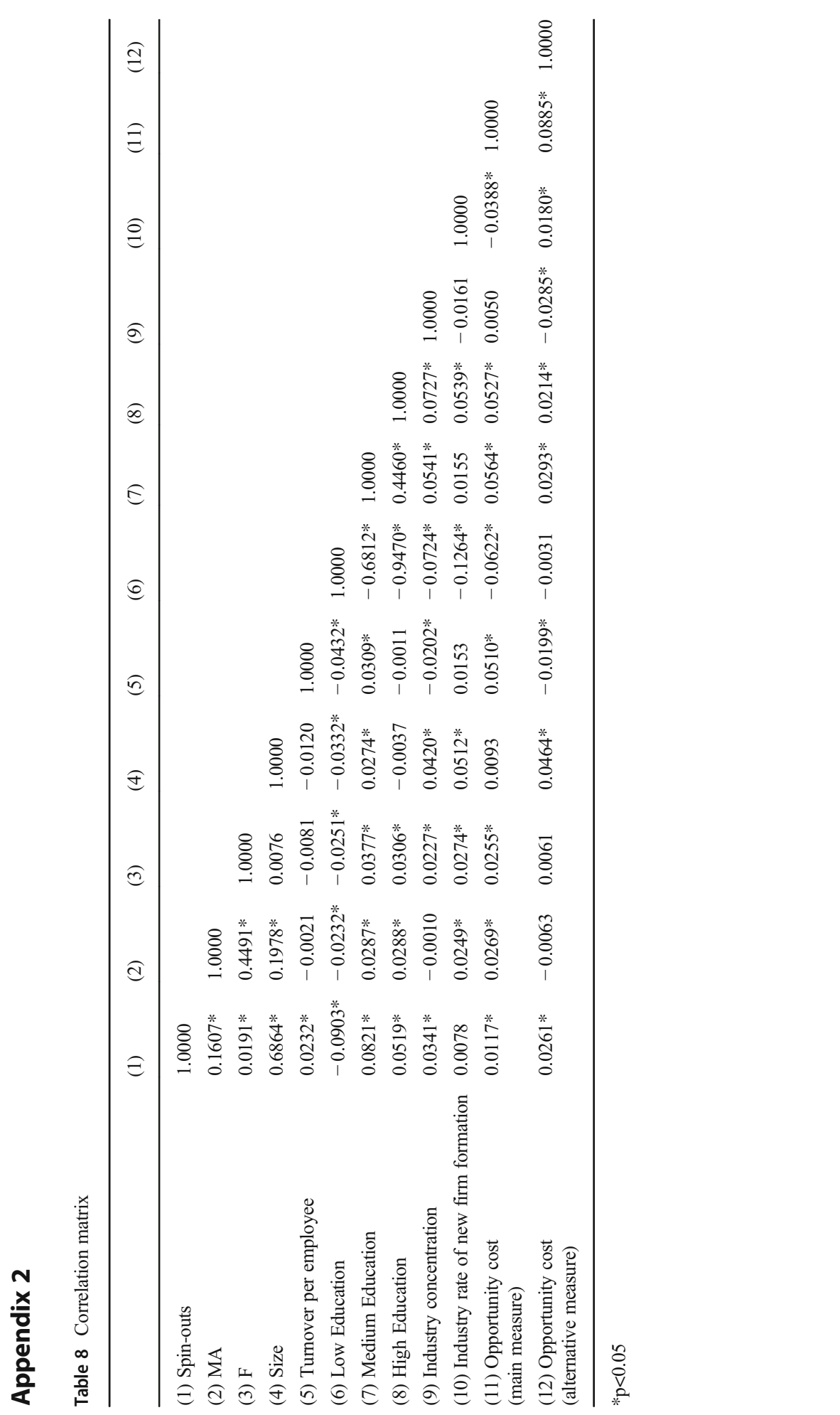




\section{Appendix 3}

Table 9 Analysis of mergers between equally sized firms

\begin{tabular}{|c|c|c|}
\hline Dependent variable & $\begin{array}{l}\text { Model A-5 } \\
\ln \text { (opportunity cost) }\end{array}$ & $\begin{array}{l}\text { Model B- } 6 \\
\text { number of spinouts }\end{array}$ \\
\hline Equal size $M \& A_{t}$ & $\begin{array}{l}0.1183 \\
(0.0925)\end{array}$ & $\begin{array}{l}0.2902 \\
(0.5440)\end{array}$ \\
\hline Equal size $M \& A_{t-2}$ & $\begin{array}{l}0.0189 \\
(0.0476)\end{array}$ & $\begin{array}{l}0.7277 \\
(0.4051)\end{array}$ \\
\hline Equal size $M \& A_{t-2}$ & $\begin{array}{l}0.0670 \\
(0.0532)\end{array}$ & $\begin{array}{l}0.3757 \\
(0.3983)\end{array}$ \\
\hline $\mathrm{MA}_{\mathrm{t}}$ & $\begin{array}{l}-0.0191 \\
(0.0119)\end{array}$ & $\begin{array}{l}0.0552 \\
(0.0468)\end{array}$ \\
\hline $\mathrm{MA}_{\mathrm{t}-1}$ & $\begin{array}{l}-0.0311^{* * *} \\
(0.0113)\end{array}$ & $\begin{array}{l}0.0008 \\
(0.0483)\end{array}$ \\
\hline $\mathrm{MA}_{\mathrm{t}-2}$ & $\begin{array}{l}0.0079 \\
(0.0117)\end{array}$ & $\begin{array}{l}0.1569 * * \\
(0.0569)\end{array}$ \\
\hline $\ln \left(\right.$ Opportunity cost $\left.t_{t}\right)$ & & $\begin{array}{l}-0.0059 \\
(0.0471)\end{array}$ \\
\hline $\ln \left(\right.$ Opportunity $\left.\operatorname{cost}_{t-1}\right)$ & & $\begin{array}{l}0.0365 \\
(0.0466)\end{array}$ \\
\hline $\ln \left(\right.$ Opportunity cost $\left.t_{t-2}\right)$ & & $\begin{array}{l}-0.0992 * \\
(0.0463)\end{array}$ \\
\hline $\begin{array}{l}\text { same set of control variables as } \\
\text { in Table } 3\end{array}$ & yes & yes \\
\hline
\end{tabular}

Open Access This article is licensed under a Creative Commons Attribution 4.0 International License, which permits use, sharing, adaptation, distribution and reproduction in any medium or format, as long as you give appropriate credit to the original author(s) and the source, provide a link to the Creative Commons licence, and indicate if changes were made. The images or other third party material in this article are included in the article's Creative Commons licence, unless indicated otherwise in a credit line to the material. If material is not included in the article's Creative Commons licence and your intended use is not permitted by statutory regulation or exceeds the permitted use, you will need to obtain permission directly from the copyright holder. To view a copy of this licence, visit http://creativecommons.org/licenses/by/4.0/.

\section{References}

Adams P, Fontana R, Malerba F (2019) Linking vertically related industries: entry by employee spinouts across industry boundaries. Ind Corp Change 28(3):529-550

Agarwal R, Echambadi R, Franco AM, Sarkar MB (2004) Knowledge transfer through inheritance: Spin-out generation, development, and survival. Acad Manag J 47(4):501-522

Aldrich H (1999) Organizations evolving. Sage, Los Angeles 
Amit R, Muller E, Cockburn I (1995) Opportunity costs and entrepreneurial activity. J Bus Ventur 10(2):95106

Andersson M, Klepper S (2013) Characteristics and performance of new firms and spinoffs in Sweden. Ind Corp Chang 22(1):245-280

Andersson M, Xiao J (2016) Acquisitions of start-ups by incumbent businesses: A market selection process of "high-quality" entrants? Res Policy 45(1):272-290

Arora A, Nandkumar A (2011) Cash-out or flame-out! opportunity cost and entrepreneurial strategy: Theory, and evidence from the information security industry. Manag Decis 57(10):1844-1860

Baltzopoulos A, Broström A (2013) Attractors of entrepreneurial activity: Universities, regions and alumni entrepreneurs. Reg Stud 47(6):934-949

Berchicci L, King A, Tucci CL (2011) Does the apple always fall close to the tree? The geographical proximity choice of spin-outs. Strateg Entrep J 5(2):120-136

Berkhout P, Hartog J, van Praag M (2016) Entrepreneurship and financial incentives of return, risk, and skew. Entrep Theory Pract 40(2):249-268

Bertrand O (2009) Effects of foreign acquisitions on R \& D activity: Evidence from firm-level data for France. Res Policy 38:1021-1031

Buenstorf G (2007) Creation and pursuit of entrepreneurial opportunities: An evolutionary economics perspective. Small Bus Econ 28(4):323-337

Buenstorf G (2016) Schumpeterian incumbents and industry evolution. J Evol Econ 26(4):823-836

Burton MD, Sørensen JB, Beckman CM (2002). Coming from good stock: Career histories and new venture formation. In: M Lounsbury, M J Ventresca (eds). Research in the Sociology of Organizations 19:229-262

Campbell B, Ganco M, Franco A, Agarwal R (2012) Who leaves, where to, and why worry? Employee mobility, entrepreneurship and effects on source firm performance. Acad Manag J 33:65-87

Capron L, Mitchell W (1998) The role of acquisitions in reshaping business capabilities in the international telecommunications industry. Ind Corp Chang 7(4):715-730

Cassar G (2006) Entrepreneur opportunity costs and intended venture growth. J Bus Ventur 21(5):610-632

Cassiman B, Colombo MG (2006) Mergers \& acquisitions: The innovation impact. Cheltenham

Cassiman B, Ueda M (2006) Optimal project rejection and new firm start-ups. Manag Sci 52(2):262-275

Chastain CE (1987) Divestiture: Antidote to merger mania. Bus Horiz 30(6):43-49

Christensen CM (1993) History of the rigid disk drive industry: A history of commercial and technological turbulence. Bus Hist Rev 67(4):531-588

Cloodt M, Hagedoorn J, Van Kranenburg H (2006) Mergers and acquisitions: Their effect on the innovative performance of companies in high-tech industries. Res Policy 35(5):642-654

Conyon MJ, Girma S, Thompson S, Wright PW (2002) The impact of mergers and acquisitions on company employment in the United Kingdom. Eur Econ Rev 46(1):31-49

Curran D, Van Egeraat C, O'Gorman C (2012) Adverse Events and Opportunistic Spin-offs: The Irish Biotech Sector, NIRSA Working Paper Series

Delmar F, Wennberg K, Hellerstedt K (2011) Endogenous growth through knowledge spillovers in entrepreneurship: An empirical test. Strateg Entrep J 5:199-226

Eriksson T, Kuhn JM (2006) Firm spin-offs in Denmark 1981-2000-patterns of entry and exit. Int J Ind Organ 24(5):1021-1040

Franco AM, Filson D (2006) Spin-outs: knowledge diffusion through employee mobility. RAND J Econ 37(4):841-860

Friberg R, Romahn A (2012) Ex-Post merger review and divestitures, IESE business school working paper

Gambardella A, Ganco M, Honore F (2015) 'Using what you know: Patented knowledge in incumbet firms and employee entrepreneurship'. Organ Sci 26(2):456-474

Gates S, Very P (2003) Measuring performance during M\&A integration. Long Range Plan 36(2):167-185

Gompers P, Lerner J, Scharfstein D (2005) Entrepreneurial spawning: Public Corporations and the Genesis of New Ventures, 1986 to 1999, J Financ LX(2)

Gugler K, Mueller DC, Yurtoglu BB, Zulehner C (2003) The effects of mergers: an international comparison. Int J Ind Organ 21(5):625-653

Habib MA, Hege U, Mella-Barral P (2013) Entrepreneurial spawning and firm characteristics. Manage Sci 59(12):2790-2804

Hamilton RT, Chow YK (1993) Why managers divest- Evidence from New Zealand's largest companies. Strateg Manag J 14(6):479-484

Haveman Ha, Cohen LE (1994) The ecological dynamics of careers: The impact of organizational founding, dissolution, and merger on job mobility. Am J Sociol 100(1):104

Henderson RM, Clark KB (1990) Architectural innovation: The reconfiguration of existing product technologies and the failure of established firms. Adm Sci Q 35(3):9-30 
Homburg C, Bucerius M (2005) A marketing perspective on mergers and acquisitions: How marketing integration affects postmerger performance. J Mark 69(1):95-113

Hunt RA, Lerner DA, Townsend DM (2019) Parental endowments versus business acumen: Assessing the fate of low-tech, service-sector spinouts. Forthcoming in Strateg Entrep J

Hyytinen A, Ilmakunnas P (2007) Entrepreneurial aspirations: Another form of job search? Small Bus Econ 29:63-80

Jaju A, Jpiner C, Reddy S (2006) Consumer Evaluations of Corporate Brand Redeployments. J Acad Mark Sci 34:206-215

James LR, Mulaik SA, Brett JM (2006) A tale of two methods. Organ Res Methods 9(2):233-244

Kaplan SN, Weisbach MS (1992) The success of acquisitions: evidence from divestitures. J Financ 47(1):107138

Klepper S, Sleeper S (2005) Entry by spinoffs. Manage Sci 51(8):1291-1306

Klepper S, Thompson P (2006) Spin-off entry in high-tech industries: motives and consequences. In: Malerba F, Brussoni D (eds) Economic Perspectives on Innovation. Cambridge Univ. Press, Cambridge, pp 187218

Klepper S (2007) Disagreements, spinoffs, and the evolution of Detroit as the capital of the U.S. automobile industry. Manage Sci 53(4):616-631

Klepper S, Thompson P (2010) Disagreements and intra-industry spinoffs. Int J Ind Organ 28(5):526-538

Lambrecht BM (2004) The timing and terms of mergers motivated by economies of scale. J Financ Econ 72(1):41-62

Larsson R, Lubatkin M (2001) Achieving acculturation in mergers and acquisitions: an international case survey. Hum Relat 54(12):1573-1607

Luksha P (2008) Niche construction: the process of opportunity creation in the environment. Strateg Entrep J 2:269-283

Mason CM, Harrison RT (2006) After the exit: acquisitions, entrepreneurial recycling and regional economic development. Reg Stud 40(1):55-73

Neffke F, Henning M (2013) Skill relatedness and firm diversification. Strategic Management Journal 34(3): 297-316

Newma JM, Krzystofiak FJ (1993) Changes in employee attitudes after an acquisition a longitudinal analysis. Group Org Manag 18(4):390-410

O'Shaughnessy KC, Flanagan DJ (1998) Determinants of layoff announcements following M\&As: An empirical investigation. Strateg Manag J 19(19):989-999

Pakes A, Nitzan S (1983) Optimum contracts for research personnel, research employment, and the establishment of 'rival' enterprises. J Labor Econ 1(4):345-365

Parker SC (2009) Why do small firms produce the entrepreneurs? J Socio-Econ 38(3):484-494

Ranft AL, Lord MD (2002) Acquiring new technologies and capabilities: A grounded model of acquisition implementation. Organ Sci 13(4):420-441

Sarasvathy SD, Dew N (2005) New market creation through transformation. J Evol Econ 15(5):533-565

Schoenberg R, Reeves R (1999) What determines acquisition activity within an industry? Eur Manag J 17(1): 93-98

Seo M-G, Hill SN (2005) Understanding the human side of merger and acquisition: An integrative framework. J Appl Behav Sci 41(4):422-443

Sørensen JB, Fassiotto MA (2011). Organizations as fonts of entrepreneurship. Organization Science 22(5): $1322-1331$

Sørensen JB, Sharkey aJ (2014) Entrepreneurship as a mobility process. Am Sociol Rev 79:328-349

Stahl GK, Voigt A (2008) Do cultural differences matter in mergers and acquisitions? A tentative model and examination. Organ Sci 19(1):160-176

Teece D (2003) Expert talent and the design of (professional services) firms. Ind Corp Chang 12(4):895-916

Thompson P, Chen J (2011) Disagreements, employee spinoffs and the choice of technology. Rev Econ Dyn 14(3):455-474

Tushman ML, Anderson P (1986) Technological discontinuities and organizational environments. Adm Sci Q 31(3):439-465

Williamson OE (1968) Economics as an antitrust defence: The welfare trade-offs. Am Econ Rev 58:18-36

Witt U (2002) How evolutionary is Schumpeter's theory of economic development? Ind Innov 9(1-2):7-22

Yeganegi S, Laplume AO, Dass P, Huynh CL (2016) Where do spinouts come from? The role of technology relatedness and institutional context. Res Policy 45(5):1103-1112

Publisher's Note Springer Nature remains neutral with regard to jurisdictional claims in published maps and institutional affiliations. 